\title{
STUDENTS IN A TIME OF QUARANTINE: TO THE PROBLEM OF METHODS OF EMPIRICAL ANALYSIS
}

\author{
Savka Viktor ${ }^{1}$ \\ Lviv Polytechnic National University, Lviv, Ukraine \\ ${ }^{1}$ Ph.D. in Sociology, Associate Professor at the Department of Sociology and Social Work
}

Background: Management of educational processes requires objective data about their condition. Ukrainian education declares the principle of orientation to the needs of students. Therefore, empirical analysis of students' life models, in particular in such extreme situations as quarantine in 2020, is an actual problem.

Purpose: substantiation of the possibility of using of quite rarely in modern sociology of education method in the empirical analysis of the problems of introducing distance learning in extreme conditions and the students reactions to that, namely analysis of students' personal documents. Such documents may be essays written by students about their experience of living under quarantine.

Methods: comparing the heuristic possibilities of the traditional sociological research method (survey) with the proposed method of content analysis of students' essays written according to a free style scheme developed by researchers.

Results: The main advantage of the proposed method of information collection is its rather low level of detachment from the everyday life of students, which allows increasing the interest of respondents to participate in the study. In this way, the researchers will get more representative data.

Conclusion: The advantages of the proposed method of empirical analysis of students' life models during quarantine dominate over its limitations, which should also be taken into account. Its application will allow not only to form a representative information base for the management of an educational institution, but also will activate students and become a media event that can be used to form a positive image of the university.

Keywords: empirical research, personal documents, essays, student behavior patterns.

Актуальність. Непросте становище системи освіти в сучасній Україні, яка перебуває у стані перманентного реформування, ускладнилося ще однією проблемою - карантинною ситуацією весни 2020 р. Управління освітніми процесами задля знаходження виходу із кризи вимагає об'єктивних емпіричних даних про їхній актуальний стан, зокрема про моделі життєдіяльності студентів у екстремальних ситуаціях.

Рівень дослідження проблеми. Проблемами аналізу трансформаційних процесів у сучасній українській освіті, зокрема питанням спроб перебудувати ऑiі на приципі студентоорієнтованості, та ставлення до цих трансформацій студентів займаються не лише фахівці у галузі педагогіки, але й соціології. Власне соціологічний аналіз модернізації освіти та відповідних їм змін у моделях поведінки всіх зацікавлених сторін, студентів зокрема, дозволяє не лише забезпечити комплексний підхід до розуміння проблем та знаходження шляхів їхнього регулювання, але й передбачає достатньо високий рівень об'єктивності зроблених науковцями оцінок, оскільки базується на емпіричній базі. Використовувані методики проведення емпіричних соціологічних досліджень, у цій царині, залишаються доволі традиційними: це переважно різного роду опитування та контент-аналіз змісту, наприклад електронних ресурсів, призначених для дистанційного навчання. Хоча застосування цих методів має ряд істотних обмежень. Виходячи 3 цього, метою статті $\epsilon$ обгрунтування можливості використання при емпіричному аналізі проблем впровадження дистанційного навчання в екстремальних умовах та реакцій на них студентів мало вживаного в сучасній соціології освіти методу: аналізу особистих документів студентів.

Традиційно застосовуваний метод опитувань студентів як споживачів освітніх послуг, у різних його варіантах, на наш погляд, не завжди $є$ ефективним. Хоча нинішні теоретики педагогіки вищої школи та керівники Національного агентства із забезпечення якості вищої освіти (НАЗЯВО), очевидно, вважають саме його чи не найважливішим інструментом для 
отримання інформації про ставлення студентів до навчання, оцінювання його ефективності у найширшому розумінні. Підтвердженням цього $є$ і одна із базових вимог до акредитаційних процедур: проведення опитування студентів з приводу розуміння ними місії та завдань освітніх програм, якості проведення занять, внесення необхідних змін у навчальні програми тощо. [Методичні рекомендації ..., 2019] На наш погляд, цей метод має істотні евристичні обмеження. Передусім, у будь-якому опитуванні присутній високий рівень формалізації. Це стосується не лише визначеного кола проблем, за які, навіть у так званих «відкритих» питаннях, респонденти не виходять, але і самої відокремленості опитувань від звичних форм життєдіяльності респондентів, що також впливає на їхню результативність. При тому не лише дослідник може маніпулювати ситуацією, закладаючи в опитувальник програмовані питання, але й респондент здатний зрозуміти очікування до нього i, відповідно, спланувати у бажаному для себе, чи дослідника напрямі свої відповіді. Тому, на наш погляд, $є$ сенс звернути увагу на ті методи збору інформації, які, по-перше, є мінімально формалізованими та більше наближеними до звичних для респондентів варіантів життєдіяльності; по-друге, дозволяють більш системно аналізувати позиції респондентів, оскільки надають можливість їм самим зачіпати ті важливі для них проблеми, які дослідник міг не передбачити у завданнях та гіпотезах дослідження. Одним із найбільш перспективних із таких методів збору інформації, на наш погляд, $є$ аналіз неофіційних, особистих документів. Його застосування дає кращу можливість зрозуміти у всій їхній багатогранності та суперечливості глибокі, часто неочевидні механізми формування інтересу, мотивацій до різних видів діяльності i, зокрема, навчання, їх реалізації у різних формах та на різних рівнях, а також проблеми, з якими студенти зустрічаються і які можуть достатньо істотно впливати на моделі їхньої поведінки тощо. Одним із прикладів застосування такого роду методу в практиці соціологічного аналізу проблем, з якими зіткнулися громадяни Польщі в час карантину, споводованого COVID-19, є оголошений у квітні 2020 р. рядом інститутів Польської академії наук конкурс «Пам'ятки пандемії». Він охоплює істотно ширше, ніж поставлені у даній статті, коло дослідницьких проблем та стосується більшого об'єкту дослідження: всіх жителів Польщі, а не лише студентів та їхнього навчання. Конкурс передбачає збір щоденників, в яких їх авторів просять занотувати « ... як виглядає Ваше повсякденне життя сьогодні: як виглядає Ваш день, щоденні обов'язки, контакти з близькими і знайомими, якими $\epsilon$ Ваші розваги, як відбувається Ваша професійна робота - якщо працюєте». [Konkurs Pamiętniki Pandemii, 2020] Очевидно, що надіслані на конкурс щоденники будуть піддані контент-аналізу, за результатами якого описуватимуться трансформації моделей життєдіяльності різних суспільних груп під впливом карантинної ситуації. Для нас тут важливою $\epsilon$ сама ідея: збір інформації не високоформалізованим та жорстко зведеним до заданих дослідниками, рамок методом, як це передбачають різні варіанти опитувань, а можливість респондентів самостійно визначити для себе поле, в якому вони будуть рефлексувати над пропонованою дослідниками проблемою. Це дещо ускладнює ситуацію аналітиків, оскільки їм, при опрацюванні зібраних даних, прийдеться зустрітися із значним інформаційним масивом, проте дозволить науковцям краще зафіксувати $\mathrm{i}$ зрозуміти часто неочевидні, чи латентні форми життєдіяльності людей, їхню не завжди усвідомлену мотивацію.

В нашій ситуації, коли слід проаналізувати проблеми, пов'язані із вимушеним переходом студентів до дистанційного навчання, приблизним аналогом польського дослідження щоденників може виступити аналіз студентських тематичних есеїв. На користь саме такого варіанту, на наш погляд, свідчить ряд аргументів: есеї, а не щоденники, оскільки ведення сучасними студентами щоденників $є$ радше винятком, а не правилом. Тому написані спеціально до конкурсу щоденники можуть зберігати лише видимість їхньої форми із одночасною відсутністю відповідного змістовного наповнення; есеї дозволяють автору, зберігаючи певний змістовний наратив, не обмежувати себе лише формальними відповідями на жорстко визначені дослідником питання. Це забезпечує можливість відкрити часто неочевидні варіанти і мотиви поведінки студентів, зокрема пов'язаність навчання із багатьма чинниками, які можуть не бути зафіксованими у дослідницьких гіпотезах, а отже і не знайти відображення у опитувальниках. 
Першою проблемою, з якою зустрінеться дослідник при плануванні збору інформації таким методом є власне мотивування студентів до написання і надсилання дослідникам своїх есеїв. Очевидно, ця проблема може бути вирішення шляхом оголошення конкурсу серед студентів. Для кращого донесення інформації про конкурс до студентів та їх вмотивування варта до проведення конкурсу максимально залучити громадські організації, органи студентського самоуправління. При тому наголос повинен робитися на добровільності участі в конкурсі, не використанні для цього засобів адміністративного впливу. Це важливо, оскільки вже сама кількість студентів, залучених до конкурсу, у співвіднесенні до їх загальної кількості в освітньому закладі та його структурних підрозділах, дозволить зробити певні висновки про рівень активності студентів, їхньої включеності у життя колективу, а отже і в комплексі з іншими показниками оцінити рівень вмотивованості студентів до навчання, частково відстежити їхню включеність у комунікативні канали закладу освіти.

Есей, який подається студентами на конкурс, повинен бути їх самостійною роботою, виконаною у вільному стилі, хоча і з дотриманням певних, заданих дослідником, тематичних параметрів, що забезпечить отримання необхідної інформації. Для залучення максимальної кількості учасників, він не повинен передбачати володіння конкурсантами навиками літературного письма. Достатньою буде проста розмовна мова із дотриманням елементарних правил граматики та стилістики, що забезпечить розуміння написаного.

Тему конкурсу слід формувати достатньо широко 3 метою стимулювання інтересу до конкурсу та отримання комплексної інформації про різні аспекти життя студентів, наприклад: «Життя під час пандемії: виклики та нові можливості». При тому, для того щоб «м'яко» ввести респондентів у бажане для дослідників русло есеї повинні бути структурованими, містити, наприклад такі компоненти:

- Ви цікавитеся/цікавилися і наскільки регулярно, перебігом епідемії в світі та Україні, протиепідемічними заходами, які вживаються міжнародними організаціями, урядами закордонних країн та України, реакціями громадськості на них;

- Вам цікава інформація про протиепідемічні заходи у нашому освітньому закладі;

- $\quad 3$ яких джерел Ви отримуєте інформацію про всі ці процеси;

- наскільки Ви довіряєте інформаційним каналам, 3 яких отримуєте інформацію про вірусну епідемію;

- на Ваш погляд, змінився і як саме Ваш та Ваших товаришів стиль життя (праця, навчання, форми проведення вільного часу);

- Ви продовжуєте навчання під час карантину, наскільки регулярно і у яких формах (заняття, консультації із викладачами та одногрупниками з використанням яких платформ тощо);

- скільки часу Ви відводите навчанню, в тому числі вивченню чогось нового, що непрямо стосується Вашої майбутньої спеціальності, які ресурси при тому використовуєте;

- $\quad$ як Ви проводите свій вільний час. Можливо, Ви відкрили у себе якісь нові таланти;

- 3 якими проблемами Ви зустрілися під час епідемії та карантину, яким чином i наскільки успішно Ви їх розв'язували;

- Ви плануєте після закінчення карантину щось змінити у своєму ставленні до навчання, проведенні вільного часу, стилі життя загалом.

Зведення теми лише до питань, пов’язаних із навчанням, на наш погляд, істотно звузить коло потенційних учасників, унеможливить проаналізувати навчальну проблематику у взаємозвязку і «на тлі» інших форм життєдіяльності, від яких вони можуть істотно залежати.

Параметрами оцінювання конкурсних матеріалів повинні стати повнота викладення інформації відповідно до вказаних питань, реалістичність, адекватність ситуації сформульованих конкурсантами пропозицій. Очевидно, що тут буде присутнім певний рівень субєктивності, якого проте не уникнути в «якісних» соціологічних дослідженнях.

Висновки. Проведення такого роду соціологічного дослідження, базованого на аналізі есеїв як різновиду неформальних особистих документів, дозволить зібрати саме неформалізовану, а отже, і достатньо об'єктивну інформацію для управлінських рішень в 
умовах криз. Впровадження нових для студентів варіантів взаємодії з адміністрацією та самоврядними структурами освітнього закладу повинно стимулювати їхню зацікавленість у навчанні та позанавчальній діяльності, підвищуватиме рівень взаємної довіри. Такий конкурс також може стати помітною медіаподією в житті міста, регіону, яка не лише формуватиме позитивний імідж закладу освіти, але й нарощуватиме соціальний потенціал інституції освіти в цілому.

\section{References}

Metodychni rekomendacii dlia expertiv Natsionalnogo agentstva chodo zastosuvannia Kryteriiv ociniuvannia jakosti osvitnioi program. (2019) // https://naqa.gov.ua/wpcontent/uploads/2019/09pdf;

Konkurs Pamiętniki Pandemii.( 2020) Instytut Filozofii i Socjologii Polskiej Akademii Nauk, Instytut Socjologii Uniwersytetu Warszawskiego oraz Instytut Kultury Polskiej Uniwersytetu Warszawskiego. //http://pamietnikipandemii.pl/

\section{Список використаних джерел.}

Методичні рекомендації для експертів Національного агентства щодо застосування Критеріїв оцінювання якості освітньої програми (2019).// https://naqa.gov.ua/wpcontent/uploads/2019/09pd;

Konkurs Pamiętniki Pandemii( 2020). Instytut Filozofii i Socjologii Polskiej Akademii Nauk, Instytut Socjologii Uniwersytetu Warszawskiego oraz Instytut Kultury Polskiej Uniwersytetu Warszawskiego. //http://pamietnikipandemii.pl/

\section{Contact information:}

\section{Savka Viktor}

Viktor.y.savka@1pnu.ua 